\title{
“Doença de Índio": o princípio patogênico da alteridade e os modos de transformação em uma cosmologia amazônica
}

Aristóteles Barcelos Neto

USP
O fato teve lugar em um hospital de Brasília, por volta do ano de 1991. Depois de acordar de um sono conturbado, Atamai, atual chefe dos Wauja ${ }^{2}$, convalescido em seu leito, diz à sua filha, Kamihã, que pessoas desconhecidas estavam a lhe oferecer cuias cheias de sangue para que ele bebesse. Atamai tinha certeza de que essas pessoas eram apapaatai.

A despeito de todo esforço dos médicos para curá-lo de uma grave infecção nos olhos, Atamai não mostrava resposta satisfatória. Inesperadamente, numa noite, Atamai foi acometido por intensa e contínua dor, que, conforme suas próprias palavras, o "matou", ou seja, colocou-o em um estado inconsciente ou, talvez, semiconsciente. Na manhã seguinte, sua filha transmitiu, via rádio, para a aldeia wauja, a notícia de que Atamai estava "morto". A notícia foi recebida por sua filha mais velha, Atsule, que imediatamente apressou-se em contratar um xamã para descobrir quem estava a causar tamanho mal a Atamai. Assim, desde Piyulaga, a aldeia wauja, várias sessões xamânicas foram feitas a fim de recuperar a saúde do "morto". Horas mais tarde, Atamai acorda e diz para Kamihã que algumas pessoas o tinham visitado, porém, dessa vez, não lhe deram cuias de sangue, apenas chegaram sorridentes e conversaram com ele, e então complementou: "agora me sinto melhor, mas ainda não enxergo bem". Contudo, seu relativo bem-estar não perdurou. Dias mais tarde, Atamai voltou a "morrer". Na oportunidade de uma breve recuperação, Atamai comunica sua urgente decisão a Kamihã:

- Filha, os médicos não vão me curar, isso que eu tenho é "doença de índio", eu quero voltar para a aldeia, para que teus tios cuidem de mim. Meu genro (o marido de Kamihã) tem que autorizar uma aeronave para me levar de volta.

“Doença de índio"? Esta é uma das principais chaves conceituais da minha etnografia sobre os Wauja. Por "doença de índio", Atamai simplesmente queria dizer 
dominado por xamãs, e não por médicos. Por trás desse breve diálogo há um esboço da cosmologia wauja. 0 princípio fundamental já está posto aí: que a doença é uma relação e que os apapaatai são um padrão que conecta relações.

Vejamos um pouco mais sobre o desenvolvimento desta história.

“Quando meu tio (Atamai) chegou na aldeia, Pakairu (sua esposa) levou uma kamalupo (panela grande usada em pagamentos rituais e xamânicos) e um colar bem grosso de miçangas para o meu irmão, Ulepe.

- Primo, você pode ver meu marido? Seus olhos estão doendo de novo. Ele sonha que está comendo carne de anta, de tamanduá, de veado. Ele diz que alguém está trazendo comida e cuia cheia de sangue de animal para ele beber.

Aí Ulepe fumou muito e começou a ver Tankwara. Ele estava vendo Atamai junto com Tankwara. Os outros apapaatai que Itsautaku (um importante xamã wauja) viu antes, Ulepe também viu.

- São as Tankwara Yanumaka nãu (i.e. Jaguares clarinetistas) que estão fazendo mal para o teu marido. Atujuwá (um tipo de máscara/"roupa") que está com ele é Jaguar também. É Jaguar que está dando sangue para ele beber."

Muito do meu tempo em campo foi dedicado a entender esse universo de seres não-humanos com capacidades patogênicas e de interação humana com os doentes graves. Mas afinal, quem são os apapaatai? Que Jaguares ${ }^{3}$ eram esses que davam sangue para Atamai beber? De um modo sumário, podemos dizer que os apapaatai expressam posições múltiplas e desiguais em escala de transformações ontológicas que os define como animais, monstros, artefatos, espíritos, heróis culturais, e/ou xamãs; essa mesma escala, em sua amplitude máxima, inclui, contextualmente, os próprios Wauja. Transformações ontológicas compreendem, aqui, as transformações da natureza dos seres, sejam nos domínios dos seus corpos, "roupas", afetos, intenções, capacidades ou perspectivas. As identidades dos seres estão diretamente ligadas ao modo como esses domínios se organizam e se apresentam, no curso das (rel)ações que os seres empreendem no mundo.

Viveiros de Castro (1977, 2002a) foi o primeiro etnólogo a lançar uma visada mais profunda sobre os apapalutápa (como são chamados os apapaatai entre os Yawalapíti) e a descrevê-los como parte de um sistema de transformações contínuo-gradativas. O material yawalapíti foi especialmente relevante para a formulação que mais tarde Viveiros de Castro (1996, 2002b) veio a fazer sobre o perspectivismo ameríndio. Os apapalutápa tiveram aí um papel importante, embora este tenha se tornado mais explícito em sua recente revisão da cosmologia yawalapíti (Viveiros de Castro 2002b). A categoria apapalutápa (apapaatai), como permite entrever esse etnólogo, instaura um problema teórico para além da dualidade entre Natureza e Cultura, remetendo-o para um terceiro domínio ontológico, a Sobrenatureza ${ }^{4}$. Assim o autor conclui seu argumento:

“Cada um destes três domínios pode ser entendido como uma perspectiva que neutraliza a posição entre os dois restantes: do ponto de vista dos espíritos, humanos e animais se assemelham; do ponto de vista dos humanos, espíritos e animais comungam aspectos essenciais; do ponto de vista dos animais, humanos e espíritos quiçá sejam a mesma coisa. Há portanto, talvez, dualidade; mas ela seria apenas a redução de uma estrutura mais rica" (Viveiros de Castro 2002a: 85). 
A fim de precisar um pouco mais a "Sobrenatureza" no contexto xinguano tomemos uma outra afirmação do mesmo autor:

“O que chamamos de sobrenatural refere-se, para os Yawalapíti, ao domínio de criação da ordem: os arquétipos dos seres e eventos do mundo atual. Mas isto que cria a ordem, escapa a ela: a prototipia é o excesso, o modelo se cria num fluxo, e a perfeição se encontra com a monstruosidade" (Viveiros de Castro 1978: 164, grifos meus).

Uma das dimensões do excesso é precisamente o extraordinário poder patogênico/terapêutico dos seres "sobrenaturais", o qual é envolvido por um fluxo de predação/produção que pulsa entre a fealdade/dor e a beleza/ prazer. A fealdade/dor, neste contexto, é muitas vezes expressa nas exegeses como um efeito da manipulação de substâncias patogênicas "sobrenaturais" por feiticeiros humanos: os artífices supremos do feio e da morte. Já a beleza é o resultado do uso correto dos meios que os seres sobrenaturais oferecem aos humanos para superarem a doença e evitarem a morte. Meus dados wauja apenas divergem da interpretação de Viveiros de Castro quanto à idéia da perfeição se situar no domínio da monstruosidade. O que parece haver é um desequilíbrio de poderes entre a humanidade e as outras formas de vida - Animais, Plantas, Fenômenos Naturais, seres míticos etc. 0 esforço wauja é voltado para o controle do perigo que esse desequilíbrio funda, e não para a sua superação. Os mitos wauja mostram que a perfeição está distribuída entre todas as séries de seres. Assim, um determinado Animal pode ter a reza perfeita para curar hemorragias, mas ele pode ser incestuoso, o que, por contraste, faz dele um ser imperfeito do ponto de vista da produção das relações de parentesco. Seres como o Jaguar e o Fogo são grandes flautistas, porém eles são tão agressivos e egoístas que fogem do ideal xinguano de autocontrole e altruísmo. É claro que ser um exímio flautista é também um ideal wauja, mas nesse sentido o que se almeja é apenas a capacidade musical dos Jaguares: nenhum Wauja almeja ser Jaguar. Portanto, há traços de perfeição e imperfeição em todos os domínios ao mesmo tempo. Vale ressaltar que os modos de transformação podem deslocar muitas dessas disposições de perfeição e imperfeição.

\section{O NASCIMENTO DO SOLE DA LUA}

Antes da humanidade só existiam Kwamutõ e os yerupoho. Os putáka (xinguanos), os kajaopa (brancos) e os muteitsi (índios "bravos" ou "os outros" índios) surgiram depois: são criação de Kamo (Sol), o neto de Kwamutó.

Kwamutõ era um velho solitário, filho da união entre o Morcego e a Jatobá. Um dia, Kwamutõ foi ao mato em busca de corda para seu arco e deparou-se com Jaguar (Yanumaka), um yerupoho ${ }^{5}$, cujo corpo era de "gente" (ז̃yãu), mas algumas partes menores "eram de jaguar mesmo", como as orelhas, os dentes, o nariz, os olhos e as unhas; Jaguar era zooantropomorfo. 


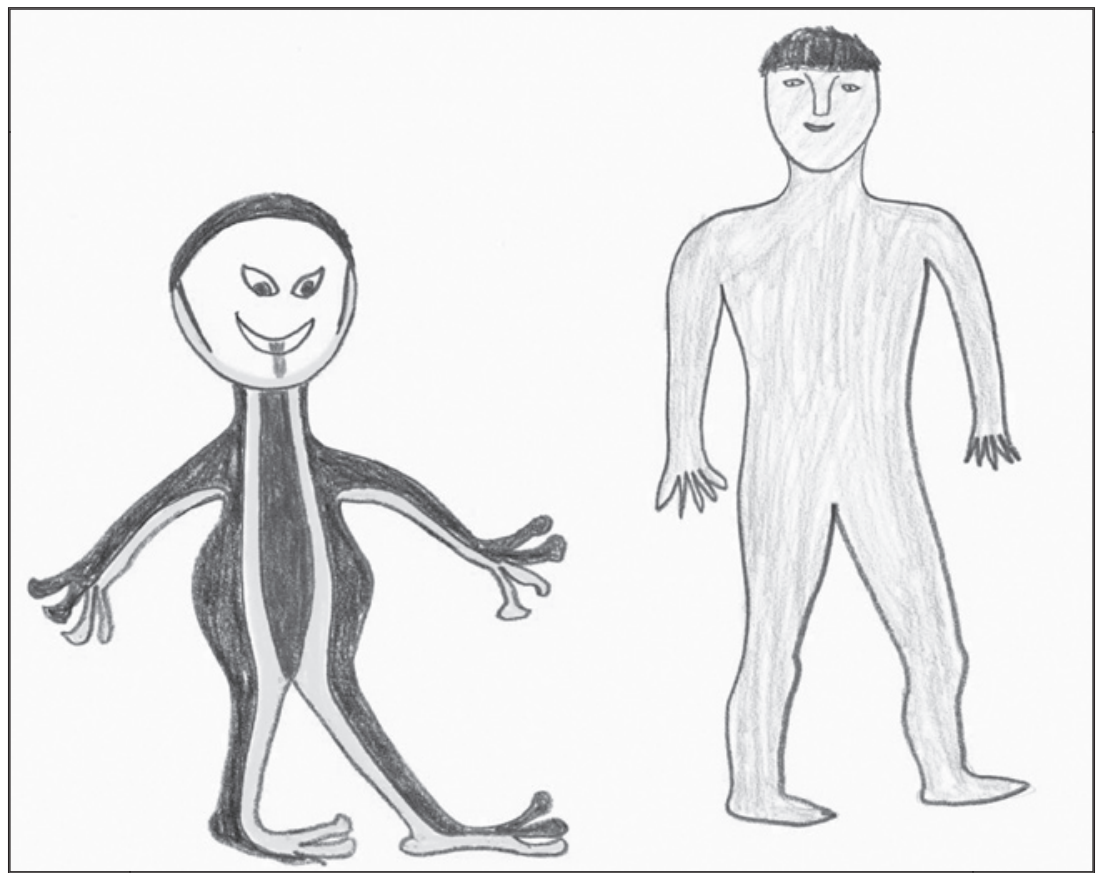

Figura 1 - Neste desenho, Aulahu faz uma comparação entre um yerupoho Wejeje (Sapo) e um wauja (humano). Embora o Sapo seja antropomorfo, nota-se claramente que seu corpo guarda características anfíbias, como a língua e os dedos das mãos e dos pés. Este Sapo raptou a alma de Aulahu anos atrás, causando-Ihe uma grave doença. O desenho retrata o passeio-rapto de Aulahu com o Sapo. O passeio-rapto corresponde a uma lenta Animalização da pessoa raptada. A reversão desse processo é garantida pelos yakapá, os xamãs visionário-divinatórios wauja. Graças a intervenções xamânicas e rituais esse Sapo tornou-se kawoká ("espírito protetor") de Aulahu. Autor: Aulahu 2000.

Inadvertidamente, Kwamutó havia adentrado o domínio territorial da Fera, que ameaçou tirar-Ihe a vida. A fim de se livrar da morte, Kwamutó ofereceu ao Jaguar suas filhas em casamento. Neste ponto, há duas versões divergentes: uma delas diz que Kwamutõ volta para casa e informa a suas filhas "originais" que elas deveriam partir rumo à aldeia do Jaguar para contraírem matrimônio com ele. A outra versão afirma que Kwamutõ, sendo solteiro, não tinha filhas "originais". Assim, a pressão do Jaguar levou-o a conceber suas filhas a partir de troncos de uma árvore chamada umejo (a mesma atualmente usada para fazer as efígies dos mortos no ritual pós-funerário Kaumai). Portanto, uma das versões afirma que Kwamutõ teria astutamente blefado em seu encontro com Jaguar. De toda sorte, Kwamutó cumpriu o acordo e mandou suas filhas ao encontro de seu futuro marido. Das cinco mulheres que Kwamutõ criou, apenas duas chegaram ao destino, as outras três morreram no caminho.

As filhas de Kwamutõ foram o protótipo do que veio mais tarde a ser o corpo humano. Antes mesmo de partirem em sua viagem, elas já eram consideradas bonitas e sexualmente desejadas por vários Animais da floresta. Elas eram uma novidade, uma beleza.

Uma delas, Atanakumalu - de ata (madeira) + kumalu (fem. de kumã: extraordinário, sobrenatural) - ficou grávida do Jaguar, mas foi morta pela sogra-Jaguar nos primeiros meses de gravidez. O corpo de Atanakumalu foi jogado no mato pela sogra. Tempos mais tarde, Kwamutó soube do ocorrido e mandou Metsukuto, uma Formiguinha, entrar pela vagina de Atanakumalu para ver se o feto ainda estava vivo. Ajudada por uma reza de 
Kwamutõ, Metsukuto retirou dois meninos do útero de Atanakumalu. Primeiro nasceu Kamo (Sol), depois Kejo (Lua). Os gêmeos foram levados para o interior da casa do Jaguar e escondidos dentro de um cesto, onde passaram sua brevíssima infância, sob os cuidados da irmã da sua mãe. Kamo e Kejo (doravante Gêmeos) desenvolveramse muito rapidamente, e, em poucos dias, já eram capazes de andar e falar; eles abandonaram o cesto e foram à procura de seu avô, Kwamutó.

Inconsoláveis com o assassinato de sua mãe, Kamo e Kejo perguntaram ao seu avô, que é um dos xamãs prototípicos, como eles poderiam trazê-la de volta. Kwamutõ explicou-lhes sobre a impossibilidade de ressuscitar Atanakumalu, e que eles apenas poderiam se lembrar dela por meio de uma festa em sua homenagem. Assim, Kamo, que é o Gêmeo mais inteligente e astuto, inventou o Kaumai, que é atualmente o ritual inter-aldeão celebrado em homenagem aos amunaw ("nobres"/chefes) recém-falecidos.

Para o Kaumai de Atanakumalu, celebrado na aldeia do Jaguar, foram convidados vários povos Peixe e os povos Ariranha (Ewejo e Awajakanĩ $)^{6}$. No Kaumai, teve lugar uma luta, idéia de Kamo para recepcionar os convidados. Rapidamente, a festa transformou-se numa chacina; Kamo tentou exterminar todos os convidados, demonstrando seu ódio pelos yerupoho em geral, inclusive pelos Felinos (Jaguares pintados, pardos e negros e Jaguatiricas, os sobrinhos de seu pai) que muito sofreram nas lutas contra certos Peixes. A essa altura, os humanos ainda não existiam. Os sentimentos de ciúme e ódio que Kamo tinha pelos yerupoho ensejaram sua vontade de transformar profundamente o mundo e de criar formas de vida distintas das que existiam.

\section{A CRIAÇÃO DOS HUMANOS}

No centro do mundo, o Mojená, local mais sagrado da cosmografia xinguana, ponto de confluência dos rios Kuluene, Ronuro e Batovi, Kamo criou os humanos a partir de arcos de madeira e de flechas de taquara, que, atualmente, correspondem aos amunaw, ("nobres"/chefes) e aos não-amunaw ("comuns"), respectivamente. Kamo colocou em pé uma longuíssima fileira de flechas, separadas, em intervalos mais ou menos iguais, por arcos em igual posição. Cada seqüência de flechas, separada por um arco, correspondia a um povo: os Wauja, os Mehinako, os Terena, os Kuikuro, os Kayapó, os Guarani, os americanos, os brasileiros etc.

Assim, a hierarquia foi a primeira distinção que Kamo criou. As distinções seguintes foram interpovos: Kamo atribuiu uma língua diferente para cada grupo, passando finalmente para a oferta de vários objetos tecnológicos sobre os quais os povos deveriam fazer uma escolha ${ }^{7}$. Os yerupoho e apapaatai, por sua vez, entendem e falam todas as línguas existentes, o que torna a língua um dispositivo muito pouco saliente na percepção das diferenças inter-ontológicas, i.e. entre humanos e não-humanos.

Assim, por meio das ações de Kamo, hierarquia - para diferenciar indivíduos no interior de um determinado grupo -, língua e tecnologia - para diferenciar grupos entre si - tornaram-se os traços fundamentais da economia simbólica da alteridade na série dos humanos. 
Quadro 1: Princípios da diferença entre as séries humana e não-humana

\begin{tabular}{|c|c|c|}
\hline Série humana & Domínios & Princípios básicos da diferença \\
\hline \multirow{2}{*}{ Nível “mínimo" de alteridade } & Interior sociopolítico & $\begin{array}{l}\text { Hierarquia (amunaw vs. não-amunaw), } \\
\text { xinguano, Língua e Tecnologia }\end{array}$ \\
\hline & Exterior sociocultural & Língua e Tecnologia \\
\hline
\end{tabular}

Progressão da diferença

\begin{tabular}{|l|l|l|}
\hline Série não-humana & Domínios & Princípios básicos da diferença \\
\hline Nível "máximo" de alteridade & Exterior sociopolítico xinguano & Corpo, Tecnologia e Língua
\end{tabular}

Dentre os três traços fundamentais, apenas a hierarquia é um valor igualmente aplicável a todos os grupos de seres; contudo, a mesma não é determinante da percepção mais ampla da alteridade, esta seguramente reservada para a tecnologia.

Os ethos da agressividade e do pacifismo, por exemplo, estão diretamente ligados a escolhas tecnológicas ocorridas no passado mítico. Os Wauja se dizem pacíficos porque escolheram a panela. Os Kamayurá são "meio" agressivos porque escolheram o arco, os Kayapó, por sua vez, são "mais" agressivos do que os Kamayurá porque escolheram a borduna, e os brancos são "mais" agressivos do que todos os índios porque escolheram a espingarda.

Se a visão do interior do socius é moldada pela hierarquia (na qual estão incluídas as diferenças de gênero), a do exterior é moldada pela tecnologia; este último critério estende-se até a série não-humana. Embora não possuam fogo e agricultura, os apapaatai e yerupoho são altamente tecnológicos. Suas "roupas" (naĩ), freqüentemente descritas como aviões supersônicos, helicópteros, submarinos e outros equipamentos do gênero, fazem parte de um imaginário de um super-poder xamânico. Contudo, do ponto de vista dos humanos, não é a tecnologia o princípio fundamental da diferença entre eles e os não-humanos, mas o corpo. Assim, se a hierarquia é o princípio básico para conceitualizar a diferença no interior das séries humana e não-humana, o corpo é o princípio central da diferenciação entre elas.

\section{UM PRINCÍPIO PATOGÊNICO}

A raiz da diferença centrada no corpo remonta ao tempo de Kwamutõ. Um dos detalhes anatômicos marcantes das diferenças corporais é a ausência de umbigo (aitsa-katukunatopai) nos yerupoho e em Kwamutõ. Isso implica que a formação do corpo desses seres não foi (ou é) submetida aos mesmos processos que correspondem à formação do corpo humano, pois não são frutos de uma gestação. 
Os sem-umbigo são considerados pukaká, ou seja, aqueles para os quais não se pode remontar a sua origem a genitores de qualquer tipo, ou aquele que "cresceu" sozinho. Tal inexistência de genitores é semantizada pela ausência de umbigo. Mas qual a implicação disso? O que os Wauja querem dizer é que um corpo sem umbigo não foi feito conforme os mesmos processos e/ou substâncias de que são feitos os corpos wauja: prolongada acumulação de esperma, misturado de alguma quantidade de sangue materno, no interior do útero. Os yerupoho, Kwamutõ e os Gêmeos podem fazer corpos sem a necessidade de cópulas, pois eles são capazes de transformar substâncias heteróclitas em corpos. Mas não é só nos modos de fabricação corporal que os yerupoho diferem dos humanos, a natureza das substâncias que eles usam também difere. Do que são feitos então os corpos desses não-humanos? As substâncias que compõem o corpo de Kwamutõ são uma preocupação ausente das exegeses wauja, mas as que originaram os yerupoho são objetos de elaborações bastante detalhadas.

Em primeiro lugar, é importante dizer que a categoria yerupoho abrange seres de atributos muito diversificados: alguns são unicamente antropomorfos, outros, zooantropomorfos, alguns são inteligentíssimos e destemidos, outros débeis e medrosos, alguns são grandes chefes, outros, grandes músicos, dançarinos, pintores etc. O que a maioria dos yerupoho tem em comum é alguma potência xamânica, manifestada de modo bastante desigual entre eles. É por meio da sua potência xamânica que os yeruhopo entram em contato com os humanos, raptam as almas destes e "negociam" a sua devolução com os xamãs humanos.

Xamanismo e sexo contínuo (leia-se reprodução biológica) são atividades incompatíveis, cuja conseqüência se nota na aversão que a maioria dos yerupoho têm ao sexo e ao seu cheiro. Tal aversão tem implicações nas formas reprodutivas dos corpos, que, entre os yerupoho, não se dão apenas por meio da cópula-gravidez-parto. Os yerupoho "mais" xamânicos não se reproduzem "biologicamente", em geral eles fazem bonecos que depois de rezados-soprados ${ }^{8}$ tornam-se seus filhos.

Há várias substâncias que podem ser usadas para formar um corpo: o das panelas cantoras que acompanham a grande cobra Kamalu Hai, por exemplo, foi modelado (criado) com as fezes da própria cobra, sendo assim até hoje; o barro que os Wauja retiram dos depósitos aluvionais são fezes deixadas por Kamalu Hai. Mas nós, os humanos, vemos como argila o que os apapaatai e yerupoho vêem como fezes.

Os yerupoho também têm sangue e esperma, substâncias elementares para a formação dos corpos, mas seus fluidos são fétidos (oho) em oposição aos mesmos fluidos dos humanos, que têm um cheiro característico, distinto do "fedor", chamado aho, noção que se aplica ao cheiro do peixe cru, do esperma, do sangue e do jenipapo (cf. também Viveiros de Castro (1977: 168) a respeito da categoria ahi entre os Yawalapíti), que por sua vez correspondem metonimicamente ao cheiro de sexo. Os yerupoho têm enorme aversão ao sangue, a substância aho por excelência, embora, paradoxalmente, comam peixe cru, um alimento aho. Já oho diz-se basicamente para as fezes, a carniça e a comida podre. Portanto, o esperma que faz o corpo de certos yerupoho é podre-fétido. Ainda que este seja esperma (gaaki), não se trata do mesmo esperma dos humanos, pois este último é ahopai e o dos yerupoho ohopai. Se as substâncias que produzem os corpos são de naturezas diferentes, igualmente os produtos que delas resultam também devem ser diferentes. 
O problema que nos interessa é que essa diferença é radicalizada: o corpo dos yerupoho existe em uma condição patológica para os humanos. Dizem os Wauja que o corpo de um yerupoho é constituído de ixana ("feitiço"), independentemente se ele foi feito de fluidos sexuais e de sangue ou de outra substância, como argila, madeira, palha etc. Assim, se um humano estabelece contatos corporais com os yerupoho, ele corre imenso risco de ficar doente ou, no pior dos casos, de morrer instantaneamente.

Em função das diferentes naturezas dos seus corpos e capacidades predatórias, a convivência dos humanos com os yerupoho, em um mesmo espaço horizontal, era impossível, restando aos humanos apenas a possibilidade vertical: viver no subterrâneo.

\section{OS REGIMES ALIMENTARES DA TRANSFORMAÇÃO}

As condições de vida dos primeiros humanos no passado mítico eram as piores possíveis: habitavam o interior mais profundo dos cupinzeiros e não possuíam os elementos fundamentais da vida civilizada - o fogo e a agricultura -, cuja posse era dos yerupoho, ou seja, dos Animais. O plano de Kamo era reverter essa situação, despossuindo os yerupoho do fogo e da agricultura, banindo-os da superfície da terra, e entregando o seu espólio aos humanos, sua criação.

No início dos tempos, o mundo era escuro. Havia apenas a noite. A única luz que havia não passava de uma leve penumbra, irradiada do fogo doméstico dos yerupoho. Fora de suas casas, os yerupoho podiam tudo ver, pois seus olhos são " como lanternas".

Há três ações de Kamo diretamente responsáveis pelo banimento dos yerupoho da superfície terrestre, pela transformação destes em animais/monstros e pela condição mais ou menos "oculta" e "marginal" em que eles passaram a viver. Primeiramente, Kamo roubou a agricultura da mandioca do povo Porco (Autopoho), juntamente com suas flautas de madeira ${ }^{9}$. Em outro momento Kamo roubou o fogo que o Urubu-Rei (Ulupu-kumã) guardava dentro da testa. Autupoho e Ulupu-kumã guardavam respectivamente o "princípio-agricultura" e o "princípio-fogo", equivalentes a toda possibilidade de cultivar e de fazer fogo. Os yerupoho ainda poderiam recuperar seus bens utilizando as mesmas espertezas de Kamo. Mas para o desespero dos yerupoho, Kamo descobriu, graças a uma informação desastradamente oferecida por seu avô, a sua única fragilidade: a impossibilidade de viverem sob o sol. Tão logo soube disso, Kamo procurou um modo de fazer o sol aparecer no céu, indo à procura de uma "máscara" (Kamo mohãjá opaka, "máscara facial vermelha de Kamo"), que pudesse "virar" o sol. Kamo arremessou-se com a "máscara vermelha" ao céu e a aurora lentamente se fez. Kejo o seguiu mais tarde, vindo a se tornar o astro lunar, também por meio de um mascaramento. Pôr fim à longa noite dos yerupoho foi a última grande ação de Kamo, que dividiu o tempo em dois: o antes e o depois do ciclo dia-noite.

Todos os yerupoho tinham imenso pavor do sol. A notícia de que Kamo pretendia "inventar" este astro já havia se espalhado muito antes mesmo dele sair à procura da sua "máscara". Logo que souberam da notícia, os yerupoho começaram a fazer "roupas"10 para se proteger do sol. 
A essa altura, há uma espécie de bifurcação do mito em duas versões complementares.

Uma delas menciona que uma variedade enorme de "roupas" e máscaras foram feitas pelos yerupoho, que, em seguida, lançaram-se para o fundo das águas. Os que não conseguiram confeccionar suas "roupas" protetoras foram "enrijecidos" pelo sol e se transformaram permanentemente em lagartixas, cobras, vermes, monstros de diversas formas ou simplesmente permaneceram ĩyãu ("gente"), embora com várias deformações.

A outra versão menciona que os yerupoho machos teriam saído para uma grande pescaria, ficando tempo demais ausentes da aldeia. As mulheres, preocupadas com a sua demora, mandam um rapaz recluso, Kamatapirá, a sua procura. Kamatapirá descobre os homens fazendo e experimentando "roupas", ele volta e avisa às mulheres que os seus maridos e parentes estavam virando "bichos". Revoltadas, as mulheres "vestem-se" com as insígnias masculinas (arcos e flechas e diademas de penas de arara, rei-congo e harpia), transformam-se em Yamurikumã (mulheres-monstro), entram num buraco cavado pelo Tatu-Canastra e abandonam a aldeia.

O objetivo desta seção não é a análise da variação mítica, mas seguir as associações que os narradores fizeram entre mitos quase sempre narrados como pertencendo a nexos diferentes. Os narradores queriam chamar atenção para o fato de que o nexo mais amplo do mito de Yamurikumã é o da grande transformação cósmica que estava em curso: o surgimento do astro solar.

Preocupados apenas em fazer suas próprias "roupas" protetoras, os homens yerupoho teriam demonstrado imenso egoísmo ao abandonarem as mulheres yerupoho à sua própria sorte. As yerupoho providenciaram um modo de se protegerem do sol e ao mesmo tempo de se vingarem dos seus maridos. As yerupoho, então transformadas em Yamurikumã, foram para o fundo da terra e os homens, com suas flautas, "roupas" e máscaras, submergiram nas águas profundas. E assim deu-se a vez da "opção vertical" se impor aos yerupoho.

É importante lembrar que nem todas as mulheres yerupoho tiveram como destino o mundo subterrâneo e muito menos a "forma" yamurikumã. Como advertem os meus exegetas, a aldeia de Kamatapirá era apenas uma dentre as milhares de aldeias de yerupoho existentes naquele tempo, na superfície do mundo. Os yerupoho eram(são) muitíssimos e muitas transformações diferentes abateram-se sobre eles.

No tempo das trevas, muitos dos animais que conhecemos hoje existiam unicamente em sua forma ĩyãu ("gente"). ĩyãu é uma categoria que, antes de tudo, define antropomorfia. Embora a noção xinguana de identidade humana esteja fortemente centrada no corpo humano (Viveiros de Castro 1977, 1979, 2002a), antropomorfia, isoladamente, não define o que seja humano (Ireland 1988, 2001). Portanto, a condição antropomorfa dos yerupoho não implica que estes sejam humanos, pelo menos do modo como os Wauja se vêem humanos.

Entre os Wauja, o humano não é uma categoria singularizada em um vocábulo. A idéia do humano é constituída, sobretudo, por um feixe de relações morais em concomitância com processos de fabricação do corpo/ pessoa (cf. também entre os Yawalapíti, Viveiros de Castro 1977, 1979, 2002a). Essa moralidade é marcada por sentimentos de vergonha-respeito-medo, expressos segundo gradientes hierárquicos - humanos têm vergonharespeito-medo dos yerupoho/apapaatai, não o inverso; já os animais têm vergonha-respeito-medo dos humanos. Porém, o que constitui o elo entre os yerupoho e os humanos são os animais ${ }^{11}$. E esse elo é moral, pois quando 
os humanos utilizam mal os recursos (e.g. pesca, caça e vegetais), seus "donos" (os Animais e Plantas) voltam-se contra os humanos, daí o respeito-medo que estes têm por aqueles.

Todos os yerupoho que vestiram "roupas" ou que foram atingidos pelo sol transformaram-se em apapaatai. A categoria cabe, neste contexto, na seguinte definição: apapaatai é tudo aquilo que, temporária ou permanentemente, tenha passado de uma forma antropomorfa para uma forma animal, monstruosa, fenômeno natural, artefatual ou uma combinação de duas ou mais destas formas. A "roupa" é o dispositivo para as transformações temporárias, enquanto as transformações permanentes originaram-se da exposição dos yerupoho ao sol e são irreversíveis.. Toda "roupa" pode ser reduzida à categoria apapaatai, mas nem todo apapaatai é "roupa".

Despossuídos do fogo, os yerupoho foram forçados a comer cru' ${ }^{12}$. Sua alimentação crua é um traço decisivo da sua condição "animal". Contudo, a "animalidade" dos yerupoho não é a mesma dos animais, pois aqueles agregam diferentes poderes xamânicos, já estes são, em sua maioria, pobres presas dos humanos ou de outros animais.

Inúmeros animais do tempo presente "mascaram" a sua condição ĩyãu em "roupas". Esses animais, uma vez despidos de suas "roupas", em geral exibem uma antropomorfia estranha, pequena estatura, pernas e braços finos, articulações protuberantes, cabeça grande sobre ombros estreitos. Além disso, seus olhos, orelhas, genitais, mãos, pés e outros detalhes anatômicos são muitas vezes semelhantes aos dos animais de hoje. Despidos, eles voltam a ser yerupoho: "gente-bicho" (Animal). A categoria que nos interessa, apapaatai, está amplamente envolvida nesse processo de vestir "roupas".

A transferência (roubo) dos bens culturais por Kamo está na base da configuração do mundo atual, que se deve a dois movimentos básicos: um de expansão - das formas de vida (pelo menos quanto aos seus aspectos anatômicos exteriores), da água, do fogo, das plantas cultivadas e da conseqüente criação de novos espaços no cosmo e a sua ocupação - e outro de inversão, ambos diretamente relacionados entre si. Ao roubar o fogo, Kamo inverteu os regimes alimentares: os humanos, que comiam apenas cru, passaram a comer cozido, e os yerupoho, que comiam cozido, passaram a comer cru. A inversão aplica-se à ocupação dos espaços do cosmo - com os humanos passando a ocupar a superfície terrestre e os yerupoho se refugiando no subterrâneo, no interior de árvores, no fundo das lagoas - e também à agricultura: os Porcos e outros yerupoho perderam o cultivo da mandioca e o espaço para cultivá-la. No entanto, hoje, vestidos de porcos, os yerupoho invadem as roças dos Wauja para devorá-las. A "roupa"-porco é "adaptada" ao veneno e à dureza da mandioca: dentes muito fortes, unhas duras para cavar e, conforme apontam os Wauja, um orifício nas costas por onde sai o veneno. A mandioca é o seu alimento perdido. Dos humanos aproximam-se os Porcos em busca do tempo em que comiam cozido. Todavia, essa busca não é deliberada. O estatuto da aproximação é variável e muito mais complexo do que o mero desejo de satisfação alimentar dos Animais.

A relação entre Porcos e porcos não possui o esquematismo que se está a apresentar. De fato, ela é ambígua e contextual. Apenas evidências muito concretas permitem, por exemplo, a um Wauja distinguir se sua roça foi atacada por porcos (apapaatai-mona, categoria genérica para os animais de pêlo, com exceção do morcego) ou Porcos (yerupoho) vestidos de porcos hiper-vorazes (apapaatai). Como estes últimos são capazes de saltar bastante 
alto, muito acima das cercas defensivas que os Wauja constroem, o estrago que eles podem fazer nas roças é imensamente maior do que aquele que os porcos eventualmente fazem. Os Porcos também são mais agressivos e não têm medo. Se um animal exibe uma agressividade incomum, os Wauja não duvidam em identificá-lo como um apapaatai, um ser muito mais próximo do pólo "monstro" do que do pólo " animal" .

A "roupa" é um dispositivo de atributos instrumentais e anatômicos - asas, no caso dos seres alados, garras e/ou presas, no caso dos predadores etc. - que enseja capacidades físico-locomotoras específicas: voar, nadar, saltar, correr velozmente etc. Os humanos são os sem-“roupa" por excelência, com exceção dos feiticeiros, que podem fazer uso de "roupas" especiais (chamadas iyeyá) para entrar nas casas de outras pessoas ou viajar a grandes distâncias em curtíssimo tempo. Uma "roupa" sempre envolve conseqüências práticas imediatas, pois ela é uma forma-função [ou uma forma funcional, sem hífen]: dentes e garras afiadas, nadadeiras, bicos alongados etc., coisas que servem para realizar tarefas específicas, as quais os humanos fazem com o auxílio de uma série de artefatos, muitos deles originalmente criados pelos yerupoho (como por exemplo o desenterrador de mandioca, tunũaĩ), e posteriormente transferidos para o mundo dos humanos via doença, xamanismo e ritual ${ }^{13}$. Como os yerupoho perderam certas tecnologias para os humanos, eles tiveram que contornar essa carência por meios anatômicos, como focinhos que revolvem a terra e dentes que perfuram cascas. Vimos que essa outra "corporalidade" (animal ou monstro) deve-se a um momento específico da ontogenia wauja e a capacidades artísticas distintas de cada yerupoho que inventou (inventa) uma diversidade desconcertante de "roupas". Todavia, há algo a mais nessa invenção que ultrapassa a mera questão do disfarce e da adaptação a uma nova situação geocósmica: trata-se da idéia de distribuição da pessoa (Gell 1998: 96-154).

\section{BREVE MORFOLOGIA DAS TRANSFORMAÇÕES}

Em um texto sobre as noções de transformação nas terras baixas da América do Sul, Peter Rivière defende a idéia de que "as vestes e a decoração do corpo de cada indivíduo fazem a mediação entre o seu eu interior, a sociedade e o cosmos" (1995: 191) 14 $^{4}$ evocando, numa determinada passagem, as artes de tecer e trançar como metonímias do ordenamento cósmico. Há muito, Lévi-Strauss (1989: 179-184) nos lembrou que em cosmética (mascaramento) há cosmo. Na cosmologia wauja, essa cosmética, ou ordenação do mundo, é baseada em princípios de transformações, cujo principal dispositivo é a "roupa".

O regime das transformações é emicamente explicitado por um grupo de quatro afixos-modificadores dos conceitos-base - -kumã, -iyajo, -mona e -malũ. Verificados tanto nas cosmologias wauja e yawalapíti ${ }^{15}$, seu papel maior é marcar/mudar a natureza das coisas e seres. Viveiros de Castro (1977 e 2002a) realizou uma análise desses afixos em sua versão yawalapíti. Não vou entrar nos pormenores das poucas diferenças analíticas que os materiais wauja e yawalapíti suscitam. De um modo geral, a análise yawalapíti de Viveiros de Castro endossa a minha análise wauja e vice-versa. 
Esses afixos distribuem, em uma escala contínuo-gradativa, que parte de estados de "insuficiência", "falsidade", "incapacidade" (-malũ), "visibilidade", "aparência", "corporalidade", "atualização" (-malũ e -mona) para estados de "invisibilidade", "alteridade", "espiritualizacão", "potência xamânica”, "prototipia” (-kumã), passando por estados de "excesso", "superioridade", "ferocidade", "veracidade" (-iyajo). Vejamos dois exemplos de como esses afixos são aplicados a um artefato - a panela (nukãi) - e a um ser - a cobra sucuri (walamá).

As panelas -malũ são aquelas que se quebram facilmente, pois são "mal-feitas", "nukãi-malü", diz-se ${ }^{16}$. O afixo -mona designa as nukai que se usam normalmente no dia a dia. -lyajo diz respeito às panelas especiais, de qualidade superior, geralmente fabricadas para pagamento ritual. Nukai-kumã são panelas prototípicas. Toda prototipia entre os Wauja remete à antropomorfia: Nukãi-kumã é uma panela-gente, um yerupoho. -Kumã confere um estatuto de sujeito à panela. Vejamos o segundo exemplo.

Uma walamá-malũ é uma cobra sucuri que falha na tentativa de matar uma grande presa por estrangulamento, é uma cobra que não consegue realizar plenamente a capacidade constrictora da espécie. As cobras sem veneno são uwi-malũ, em contraste com as cobras venenosas, que são uwi-iyajo: "verdadeiramente cobras", conforme também entre os Yawalapíti (Viveiros de Castro 2002a) Uma walamá-iyajo é uma sucuri em sua capacidade constrictora plena, é aquela capaz de matar grandes presas. As Walamá-kumã são as sucuri-gente - yerupoho, ou estes vestidos com "roupas"-sucuri -, elas postulam, em função da sua prototipia, um plano de subjetividade e de ação patogênica.

Emicamente, o afixo -mona não se aplica aos répteis e demais ordens animais, à exceção dos mamíferos, que são apapaatai-mona. Em trabalhos anteriores (Barcelos Neto 2001 e 2002) empreguei o afixo -mona como um recurso metodológico para analisar a distinção entre animais ("seres-mona") e apapaatai ("seres-kumã"). Este mesmo sentido metodológico é retomado neste trabalho, como se observa nas linhas 1, 2, 5, 6 e 10/coluna 5 do esquema abaixo.

Quadro 2: Os modos da transformação

\begin{tabular}{|l|l|l|l|l|l|}
\hline $\begin{array}{l}\text { Disposição } \\
\text { serial primária }\end{array}$ & $\begin{array}{l}\text { Modo } \\
\text { transformativo }\end{array}$ & $\begin{array}{l}\text { Disposição } \\
\text { serial secundária }\end{array}$ & $\begin{array}{l}\text { Disposição } \\
\text { formal }\end{array}$ & $\begin{array}{l}\text { Propriedades } \\
\text { dos seres }\end{array}$ & $\begin{array}{l}\text { Modo } \\
\text { predatório }\end{array}$ \\
\hline yerupoho & $1 . \longrightarrow$ & animais & corpo & -mona ou -malũ & - \\
\hline yerupoho & 2. $\longrightarrow$ & animais & "roupas" & -mona ou -malũ & - \\
\hline yerupoho & $3 . \longrightarrow$ & $\begin{array}{l}\text { apapaatai } \\
\text { ("espíritos") }\end{array}$ & "roupas" & -kumã & doença \\
\hline yerupoho & $4 . \longrightarrow$ & $\begin{array}{l}\text { apapaatai } \\
\text { (monstro) }\end{array}$ & corpo & -iyajo & canibalismo \\
\hline humanos & $5 . \longrightarrow$ & animais & corpo & -mona ou -malũ & - \\
\hline
\end{tabular}




\begin{tabular}{|c|c|c|c|c|c|}
\hline $\begin{array}{l}\text { Disposição } \\
\text { serial primária }\end{array}$ & $\begin{array}{l}\text { Modo } \\
\text { transformativo }\end{array}$ & $\begin{array}{l}\text { Disposição } \\
\text { serial secundária }\end{array}$ & $\begin{array}{l}\text { Disposição } \\
\text { formal }\end{array}$ & $\begin{array}{l}\text { Propriedades } \\
\text { dos seres }\end{array}$ & $\begin{array}{l}\text { Modo } \\
\text { predatório }\end{array}$ \\
\hline humanos & 6. $\longrightarrow$ & animais & "roupa" & -mona ou -kumã & doença \\
\hline humanos & 7. $\longrightarrow$ & animais & alma/corpo & -mona & $\longrightarrow$ \\
\hline humanos & 8. $\longrightarrow$ & $\begin{array}{l}\text { apapaatai } \\
\text { ("espíritos") }\end{array}$ & "roupa" & -kumã & doença \\
\hline humanos & 9. $\longrightarrow$ & $\begin{array}{l}\text { apapaatai } \\
\text { (monstro) }\end{array}$ & corpo & -iyajo & canibalismo \\
\hline artefatos & 10. $\longrightarrow$ & animais & corpo & -mona ou -malũ & $\longrightarrow$ \\
\hline animais & 11. $\longrightarrow$ & $\begin{array}{l}\text { apapaatai } \\
\text { (monstro) }\end{array}$ & corpo & -іуајо & canibalismo \\
\hline
\end{tabular}

Os modos transformativos 1 e 4 são irreversíveis, e ocorreram, sobretudo, no tempo do surgimento do astro solar (figura 2). Os modos 5, 9, 10 e 11 também são irreversíveis, contudo sem qualquer relação direta com o surgimento do astro solar. São dignas de nota algumas particularidades dos modos 1,5 e 11.

Em geral, esses modos são definitivos quando está em foco a espécie zoológica. Um exemplo célebre é a transformação do meninobebê de Alawiru (personagem mítica) em macaco-prego. Neste caso, é a forma corporal macaco-prego que deve sua origem ao filho de Alawiru; isso não quer dizer que cada macacoprego, individualmente, tenha se originado dessa criança. Outros macacos-prego podem ser apenas uma "roupa" a imitá-lo, sendo incógnita a sua identidade interior; mas este é exatamente o objetivo de muitos yerupoho e feiticeiros: passarem-se por macaco-prego.

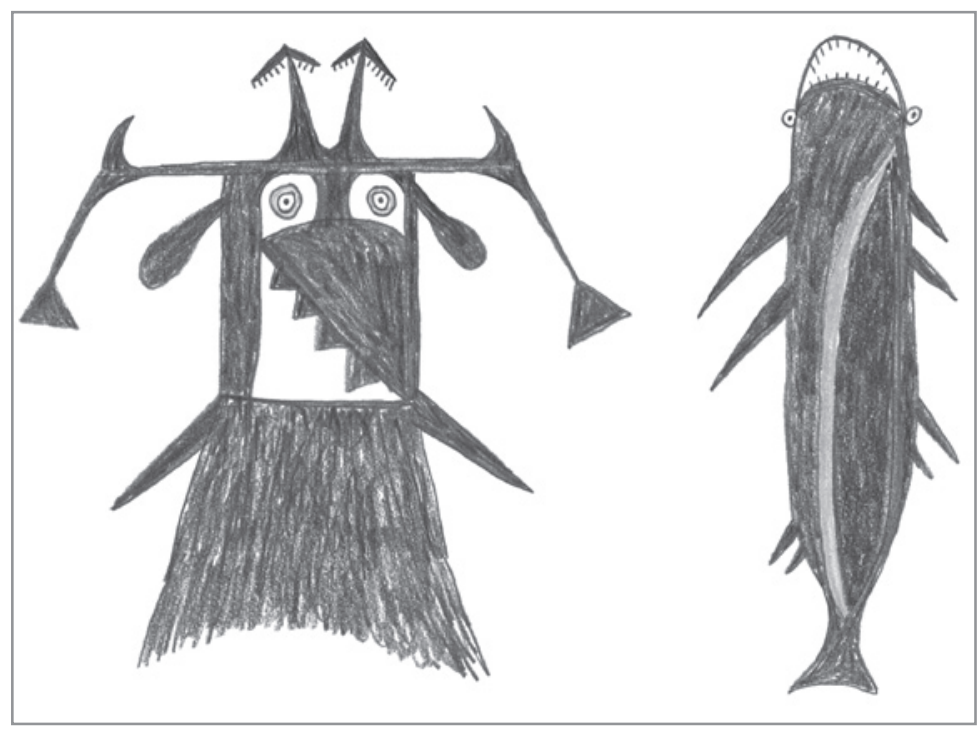

Figura 2 - Duas formas do peixe-pato (talapi). À esquerda a forma "roupa" (apapaatai), com enormes esporões e flechas a evidenciar o seu poder patogênico/letal. À direita a forma peixe, animal consumível, ser de natureza mona ("ordinária"), sem poderes sobrenaturais. Ambos são transformações de um mesmo "princípio" Animal (antropomorfo), existente no mundo antes do surgimento dos humanos. Autor: Kamo 1998. 
A condição ontológica "animal" é sempre ambígua e incerta, na medida em que ela está sujeita a sofrer uma transformação radical. Observe-se que as possibilidades transformativas dos animais são reduzidas a apenas um modo. Ora, os animais já são, em sua maioria, o resultado de uma transformação pregressa. 0 modo 11 diz respeito a uma transformação de uma transformação. E neste caso não há uma transformação "de volta": uma vez que um ser qualquer se torna monstro (apapaatai-iyajo), ele será para sempre monstro. A transformação de animais em monstros é devida sobretudo a mudanças repentinas de seus hábitos alimentares (e.g. um animal de uma espécie tipicamente herbívora alimentar-se de carne ou de animais mortos), a comportamentos agressivos inesperados, ou a uma deformação anatômica. A transformação dos humanos em monstros também tem, em alguns casos, ligação direta com os hábitos alimentares. Um dos casos mais célebres é o de um grupo "de antigamente" que comeu porcos, resultando na sua transformação em um grupo de "bicho brabo" (apapaatai-iyajo).

Todos os modos são, em maior ou menor medidas, relacionantes e relacionados. Assim, animal, monstro, humano e yerupoho são potencialmente equivalentes em função das possibilidades transformativas que abrangem suas relações. É neste sentido que um animal que era humano pode se transformar em monstro (apapaatai-iyajo), o fim da linha das transformações, daí não há mais nada, apenas pura predação e canibalismo. Este é um caso seqüenciado dos modos 5 e 11. Outra possibilidade seqüenciada é entre os modos 1 e 11.

No modo transformativo 6, vemos seres humanos transformando-se em animais por meio do uso de "roupas". Esse modo é intencional e premeditado (e não acidental como no caso do modo 7, vide análise abaixo), pois, para os humanos, a "roupa" é sempre uma forma eletiva de transformação. O uso de "roupas" fora do ritual é visto como uma ação típica de feiticeiros. Essas "roupas" são conhecidas por iyeyá. Cada feiticeiro possui uma iyeyá específica que ele usa quando precisa se aproximar de alguém sem ser reconhecido. Muitos deles vestem a iyeyá de pequenos animais de estimação, os quais podem facilmente se infiltrar na casa de alguém para fazer o mal.

O modo transformativo 7 pode ocorrer quando há eclipses. Se durante um eclipse, solar ou lunar, uma pessoa estiver dormindo e não acordar, e se no seu sono ela tiver um sonho com um animal de pêlo (apapaataimona), há possibilidades de ela se transformar nesse animal. A depender do que se passa no sonho (um grande susto com o animal, por exemplo), a alma do sonhador começará a acompanhar esse animal em outros sonhos e progressivamente ela se animalizará. Mais tarde, a pessoa, em corpo, ao sair para o mato, poderá ser "guiada" por sua alma para um caminho desconhecido e não mais voltar para a aldeia. Perambulando pelo mato ela encontrará seus "amigos" animais e finalmente se juntará a eles e se transformará definitivamente em um deles.

A reversão da monstruosidade/animalidade só é possível quando o dispositivo da transformação é intencional e programado, ou seja, quando ele se dá por meio da confecção e do uso de "roupas" (modos 2, 3, 6 e 8). Esta é uma transformação "controlada". Já os modos definitivos de transformação são acidentais e imprevisíveis. Quando há eclipses, por exemplo panelas zoomorfas, canoas, cestos com motivos gráficos e outros artefatos podem transformar-se em animais: uma canoa pode tornar-se uma cobra (modo 10). Contudo, ao fim do eclipse ela não volta a ser uma canoa. E essa mesma cobra, em outro contexto, pode transformar-se em uma cobramonstro (apapatai-iyajo): um caso seqüenciado dos modos 10 e 11. Noutros tempos, na época de Kwamutõ e 
Kamo, quando os humanos foram criados, artefatos também transformavam-se em humanos, mas isso já não acontece mais.

Os modos reversíveis de transformação são aqueles que implicam o uso de "roupas". Os humanos vestem "roupas" por motivos rituais ou de feitiçaria. Fiquemos com o uso de "roupas" pelos yerupoho (modo 3) que os transforma em apapaatai, um atributo diretamente ligado à multiplicação de suas almas, função da sua potência xamânica. Embora o modo 4 também se refira à transformação dos yerupoho em apapaatai, ele não nos interessa, pois o mesmo não implica em adoecimentos, trata-se da transformação dos yerupoho em monstros canibais, os apapaatai-iyajo. Interessa-nos o yerupoho em sua condição de monstro "travestido", aquela que o torna um apapaatai agente de doenças, portanto um futuro personagem ritual. Os apapaatai-iyajo predam o corpo e a alma de suas vítimas a um só tempo, já os apapaatai-"roupa" (ou simplesmente apapaatai) são antes raptores de almas humanas, e não predadores no sentido estrito do termo.

Quando um yerupoho multiplica sua alma, cada unidade resultante da multiplicação poderá vestir uma "roupa" singular, em geral, feita exclusivamente para cada unidade, por isso as "roupas" possuem um repertório formal vastíssimo. Dentro dessas "roupas" os yerupoho vagam pelos espaços do cosmo em busca de contato com os humanos. Essa transformação é entendida como uma "espiritualização" ("xamanização") dos yerupoho, dos Animais, portanto. Em um estado de multiplicidade as almas dos yerupoho são espíritos-Animais-monstros, apapaatai, portanto. Tal estado de multiplicidade corresponde igualmente a um estado de multiplicidade das "roupas". As "roupas" são formas-padrão de como os yerupoho manifestam-se nos sonhos e transes dos xamãs visionário-divinatórios (yakapá) e nos rituais. Esta é a condição que os yerupoho querem ser vistos pelos yakapá, com "roupas" a disfarçar a fealdade de seus rostos e corpos. As "roupas" são peças de design, equipamentos para voar, mergulhar, caçar, devorar e espalhar substâncias patogênicas.

Os yerupoho manifestados enquanto "roupa" (i.e. enquanto apapaatai) são invisíveis aos sentidos normais dos seres humanos. Mesmo o doente que tem sua alma raptada, portanto em uma condição sensorial alterada, raramente os vê. Como dito acima, a alma do doente interage com os yerupoho em sua forma antropomorfa (Ĩyãu). A máscara é uma imagem que predomina como ponto de vista da relação entre os yakapá e os apapaatai.

A alguém que usa uma "roupa-porco" é facultado ver o mundo (ou estar no mundo) como os porcos o vêem. O uso de "roupas" efetiva o ponto de vista do outro. Mas não há uma "roupa"-humana que permita aos porcos verem o mundo como os Wauja o vêem. Os próprios modos da transformação indicam essa impossibilidade. As "roupas" operam sob um regime limitado. Compare-se, por exemplo, a teoria wauja das "roupas" com a teoria juruna da distinção entre natureza e cultura tal qual explicitada por Lima:

“Tomado em sentido estrito, o ser humano, vivo e desperto, apresenta uma irredutibilidade que eu não poderia deixar de ressaltar: sua inimitável "sabedoria". (...) A sabedoria humana consiste naquilo que nós mesmos chamamos de reflexividade: os vivos sabem que os mortos consideram o tucunaré como um cadáver, mas os mortos não sabem que se sabe isso a seu respeito, nem que os vivos consideram o tucunaré como tal. Essa sua relativa insensatez, ou seja, essa incapacidade de perspectivar a si mesmos caracteriza também a nossa existência onírica e os animais. O porco se sabe humano, sabe que um Juruna é um semelhante, mas não sabe que é um porco para os Juruna" (1999: 49-50). 
A complexidade da categoria apapaatai adquire contornos mais definidos à luz de quatro afixos-modificadores dos conceitos e coisas --kumã, -iyajo, -mona, -malũ. O sufixo-kumã indica espiritualização/potência e os sufixos -mona e -malũ indicam corporificação/atualização. Como descrevi alhures (Barcelos Neto 2002: 143-146), os seres que estão no pólo da corporificação possuem uma ligação anímica direta com os seres que estão no pólo da espiritualização. O que eu não descrevi com profundidade é como essa ligação é pensada pelos exegetas Wauja.

Uma das noções capitais para esta ligação é a de "dono" (wekeho). Por exemplo, o Jacaré (Yaká-kumã) e o Beija-Flor (Kumesi-xumã) são "donos" do pequi, o primeiro em função dessa fruta ter se originado dos seus testículos, o segundo por ter uma predileção pela fruta, e, em função disso, ter sido um dos primeiros Animais a cultivá-la. $\mathrm{O}$ "dono" é sugerido por Viveiros de Castro como um "mediador":

“O wököti [wekeho em wauja] é aquele humano ou espírito que faz a conexão entre o objeto e o grupo, facultando o acesso (material ou ideal) do coletivo ao recurso de que é dono. Neste sentido, o wököti é um representante, mas que se define pelo que representa; se ele objetiva o recurso para a comunidade, é, por seu turno, subjetivado por ele" (2002a: 83, grifos meus).

O "dono" concede e ao mesmo tempo protege os recursos. Assim, o protetor do malaho (jacutinga, Pipile sp.) é o Malaho-kumã, a "dimensão espiritual" e patologicamente poderosa do primeiro, capaz de agir contra quem faça "mau" uso do recurso, a caça, neste caso, o malaho. Nesta etnografia, intessa-nos menos os animais do que os Animais, pois no âmbito da patologia - e por extensão os rituais de apapaatai - apenas os Animais são de fato agentes.

É a própria noção de wekeho que conecta um objeto e um grupo e não apenas um "dono" específico. A noção de "dono" conecta Beija-Flor, beija-flor, pequi e consumidores de pequi, e, em um sentido mais amplo, conecta estes à Festa do pequi e ao patrocinador desta, que não por acaso é alguém que sofreu de uma doença causada por Kumesi-xumã (Beija-Flor). Em um outro caso, a noção de wekeho conecta um desenho e seu desenhista ao "dono" do desenho, invariavelmente um apapaatai. Se, em uma situação solene, o desenhista revelar desleixo com seu trabalho, ele poderá ter seu desrespeito "cobrado" como doença. A categoria wekeho define relações de representação (no sentido de representante, cf. Gell 1998: 98) e de substância (Viveiros de Castro 2002a: 83), as quais são atualizadas por meio de corpos, artefatos, alimentos ou expressões artísticas.

Em um trabalho anterior (Barcelos Neto 2002), abordei os apapaatai sobretudo como uma manifestação corporal e indumentária (a noção de "roupa"). Desdobramentos dessa noção permitem demonstrar que as "roupas" correspondem a uma condição específica da alma dos yerupoho.

Certa feita, perguntei a um colaborador, muito atento às questões cosmológicas, e também capaz de reflexões agudas sobre as mesmas, se os yerupoho tinham (eram) corpos (materiais) ou apenas almas ("espíritos", entidades imateriais). Ele me deu uma resposta curta: "mas é claro que eles têm [são] corpo. Eles não morreram 
quando o sol apareceu". Isso quer dizer que o pólo da "espiritualização" não é um pólo anti-corporal. Porque nós, os humanos, não os vemos ordinariamente não significa que os yerupoho não existam enquanto corpos (lembre-se que a grande maioria deles está no extremo fundo das lagoas e dos rios); apenas não temos fácil acesso aos seus corpos, e nem devemos ter, pois eles são mortais ou patogênicos para nós. Desde há muito, Kamo se encarregou de afastá-los dos humanos. Os corpos animais com os quais nos deparamos são apenas "réplicas enfraquecidas" (para usar uma expressão de Viveiros de Castro 2002a) dos apapaatai: jaguares, veados, porcos, ariranhas, antas, coatis e demais animais de pêlo são apapaatai-mona, i.e. "parecidos" a apapaatai.

Um dado yerupoho é um correspondente antropomorfo de uma dada espécie animal, e seu corpo é uma unidade forma/ singular e prototípica para aquela espécie. Assim, o jacaré tem pele muito áspera, boca alongada, dentes afiados, os olhos estufados porque o Jacaré também os têm: os yerupoho guardam as características prístinas e fundamentais das espécies animais, pois a sua anatomia atual já estava minimamente anunciada nos yerupoho. Um dado yerupoho também corresponde a uma unidade subjetiva, a uma pessoa "não-humana". Todavia, em função das suas potencialidades xamâmicas, os yerupoho podem expandir essa unidade subjetiva por meio da multiplicação da sua alma, ou seja, do princípio de subjetividade.

O uso etnográfico do conceito de alma na Amazônia indígena não tem, obviamente, nenhuma ressonância com o seu equivalente na filosofia e teologia ocidentais. O problema amazônico não é de transcendência, e sim de imanência da alma. O caso wauja mostra que a alma é antes um "outro corpo". Segundo Viveiros de Castro:

“A leitura tradicionalmente platonizante feita do dualismo indígena do corpo e da alma, que o toma como opondo aparência e essência, deve assim dar lugar a uma interpretação dessas duas dimensões como constituindo o fundo e a forma uma para outra: o fundo do corpo é o espírito, o fundo do espírito é o corpo" (2002c: 444).

O corpo dos yerupoho não muda, exceto se forem expostos ao sol. O que muda são suas aparências, as "roupas" que eles vestem. O que está no interior da "roupa" só pode ser seguramente identificado por um yakapá. A "roupa" é a síntese de uma ontologia da ambigüidade, ela tem a capacidade de instaurar dúvidas.

Nas conversações em português, os Wauja traduzem apapaatai por "espírito". Se se insiste em outras traduções e se estabelecem cotejamentos, ver-se-á que a tradução guarda sutilezas. Assim, os apapaatai, que são monstros canibais (apapaatai-iyajo), os Wauja não traduzem por "espírito", mas por apapaatai "de verdade", ou seja, "bicho brabo" - já os apapaatai-mona são os "bichos de pêlo", aqueles que não se come17, os quais os Wauja podem, em certos contextos, simplesmente chamar de apapaatai (i.e. sem afixação específica), conforme o seus comportamentos e hábitos alimentares estranhos (Barcelos Neto 2002). São os apapaatai onaĩ ("roupas" sobrenaturais, ou melhor, yerupoho vestidos em "roupas") que os exegetas confirmam ser aquilo que eles traduzem por "espíritos". Em muitos casos, yerupoho é também traduzido por "espírito".

Durante o rapto da alma pelos apapaatai, o doente os vê como "gente" (ĩyãu), que ele chama pelo nome da espécie Animal. Essa "gente" normalmente leva a alma do doente para suas aldeias ou para pescarias e caçadas. Na fase crítica do adoecimento, os apapaatai "familiarizam" o doente por meio da oferta de carne crua 
e sangue; isso equivale a sua Animalização, cujo efeito sociocósmico corresponde à produção do parentesco. Conforme Fausto:

“Comer como alguém e com alguém é um forte vetor de identidade, assim como se abster por ou com alguém. As partilhas do alimento e do código culinário fabricam, portanto, pessoas da mesma espécie" (2002: 15).

A oferta de comida envolve ainda outras questões. Peter Rivière refere-se a um mito tiriyó em que humanos oferecem comida aos queixadas a fim de estabelecer uma relação de troca, cujos "termos são alimentos cultivados e respeito, de um lado, e um suprimento moderado de caça, de outro" (2001: 47). Reside nas formas alimentares um dos modos centrais da transformação nas cosmologias ameríndias. Cru e cozido não apenas evocam a distinção Natureza e Cultura e a passagem de uma para a outra, mas também afectos e possibilidades transformativas. Em um texto pioneiro, Peter Rivière (1995) cita um mito tiriyó em que um rapaz veste "roupa" de jaguar e lambe o sangue cru da caça abatida, "em conseqüência, ele não conseguiu mais tirar suas roupas: elas grudaram nele e ele se tornou um jaguar, não só em aparência, mas em realidade". Comer como jaguar torna alguém jaguar.

Por meio do que a alma do doente comeu, os xamãs são capazes de identificar com qual ou quais apapaatai ela está, pois o doente sempre vomita a comida crua que ele ingeriu. Esta questão se entrelaça com a condição de materialidade do "espírito". O sonho (passeio) do doente e o transe do xamã revelam a condição material do mundo dos apapaatai. As provas são os objetos patogênicos retirados do corpo dos doentes e seus vômitos e fezes. A alma do doente transubstancia no seu corpo a materialidade encontrada no mundo dos seres sobrenaturais. A identificação xamânica dos nomes dos apapaatai que estão causando a doença permitirá que os mesmos sejam ritualmente formalizados como máscaras, aerofones, outros objetos rituais ou coros femininos, e conseqüentemente que a terapia assuma uma fase muito mais eficaz e ampla (Barcelos Neto 2004).

As noções de corpo (monapitisi), imagem (potalapitisi) e cópia (upeke) articulam-se mutuamente para um entendimento geral da noção wauja de alma. Resumidamente, podemos definir a alma humana como um duplo material/visual do corpo, passível de ser multiplicado enquanto imagem e igualmente de ser subtraído do corpo enquanto substância vital. Já a alma dos yerupoho é também passível de ser multiplicada, mas a multiplicação não implica em uma subtração de substância vital de seus corpos. Esta diferença é tão essencial quanto os yerupoho terem um corpo feito de substâncias patogênicas e os humanos terem um corpo "de carne e osso". O resultado dessa "equação" é simples: humanos adoecem, os yerupoho raramente adoecem.

A multiplicação da alma corresponde a uma propagação imagética/substancial do corpo, semelhante a um fractal. Além de uma equivalência visual com o corpo, a alma também tem uma equivalência substantiva. $A$ alma do yerupoho que vagueia por aí tem a mesma potência patogênica do seu corpo. E a alma raptada aos humanos pelos yerupoho/apapaatai carrega consigo a substância vital que anima o corpo, só que esta, ao se multiplicar, subtrai na mesma medida a potência vital do corpo. Paradoxalmente, contudo, as almas humanas sobrevivem ao contato direto com os yerupoho/apapaatai, já seus corpos morrem. Isso indica, mais uma vez, a incompatibilidade dos corpos dos humanos e dos yerupoho, mas não a incompatibilidade das suas almas, ou ainda da alma humana com o corpo dos yerupoho. 
O corpo (monapitisi) é a matriz visual absoluta da alma. Assim, se alguém teve um braço amputado ou se ficou paralítico, sua alma terá essas mesmas características no post-mortem. No céu, as almas são espacialmente agrupadas em diferentes aldeias, conforme o tipo de morte que os corpos sofreram; os mortos por atropelamento, tuberculose, acidente, derrame, tiro, facada etc. agrupam-se cada qual em sua aldeia específica. A continuidade da vida como alma depende da forma última do corpo logo após a morte. A preservação e os cuidados funerários com o corpo são imbuídos de especial meticulosidade, como em nenhuma outra ocasião, pois terão um efeito idêntico sobre a alma. Assim como os Ashuar, os Wauja também endossam a idéia de que o "corpo é a melhor imagem que podemos ter da alma e vice versa" (Taylor 1994: 206). Contudo, Wauja e Ashuar elaboram de modo distinto as conseqüências dessa semelhança.

Upapitsi é a glosa que estou traduzindo por alma. O prefixo upa (de upawa, outro), associado à raiz pitsi, nos dá a idéia de que a alma é um "outro pitsi" (um outro corpo/forma). As exegeses que recolhi apontam para um tipo de sinonímia entre upapitisi e potalapitsi. Gregor explica a noção mehinako de potalapitsi da seguinte maneira:

"patalapiti is a representation of something that is real, but the representation has a reality of its own. The picture of a spirit can be dangerous because, like all pictures, it includes at least some of the features that define real, substantial things, such as form or shape" (1977: 41).

Mais do que conterem realidades em si mesmas, as imagens têm o poder de serem potencialmente vivas: uma reza correta ou um eclipse podem animá-las, e, em estados alterados de consciência, elas podem se mostrar vivas para quem as vê.

Upeke é a outra noção chave para o entendimento da alma wauja, seja em contextos gerais ou no contexto do seu "rapto". Traduzo upeke por cópia, i.e. por algo que está em uma relação de "igualdade" com um outro. A cópia tem um valor imagético, é claro, mas ela é mais do que imagem; mesmo que tal relação de "igualdade" esteja ancorada na visualidade é necessário pensar a cópia como dotada de atributos outros que não apenas aqueles circunscritos à percepção de imagens. No campo semântico da relação corpo-alma, upeke pode ser melhor entendido como "duplo" - aqui nos deparamos novamente com o pensamento de Taylor (1994): tanto a alma é uma "cópia" do corpo quanto este daquela.

Seguindo esse campo de problemas, a noção upeke mostra-se um pouco mais complexa que a de potalapitsi, e também mais central para o entendimento do rapto da alma. De um modo sumário, o rapto consiste em "copiar" a alma a partir de um contato direto do raptor (o apapaatai) com o corpo da vítima. A condição de multiplicação da alma de um yerupoho é "xamânica" e voluntária. Para os humanos, essa mesma condição é patológica e involuntária.

Conforme os dados provenientes das exegeses míticas, é possível dizer que a ontologia wauja concorda que "a condição original aos humanos e animais não é a animalidade, mas a humanidade" (Viveiros de Castro 1996: 119, grifos do autor). No tempo antes do Sol, os Animais tinham a posse do que fazem, hoje, os humanos serem humanos - o fogo e a agricultura - e, portanto, do que faziam, naquele tempo, os yerupoho serem plenamente humanos. Aos Wauja parece interessar menos um provável "fundo comum" entre humanos e não-humanos do 
que como lidar com as diferenças atuais entre eles. Minha hipótese é que o nexo das relações entre humanos e não-humanos tem como princípio a aproximação produtiva dos dois pólos, por meio de uma minimização das diferenças entre ambos. A possibilidade de aproximar os dois pólos é dada pelas doenças graves e pelo ritual.

Os eixos conceituais da diferença entre humanos e seres sobrenaturais passam pelo corpo (patogênico ou "de carne e osso") e pela tecnologia (posse ou não do fogo e da agricultura). As diferenças são minimizadas (1) quando os humanos estão doentes, ou seja, com seu corpo repleto de "feitiços" e sua alma a passear com os apapaatai; (2) quando um Wauja mantém em seu corpo os feitiços especiais doados pelos apapaatai, fazendo dele um xamã, ou melhor, alguém próximo de um estado permanente de adoecimento, o que o coloca constantemente próximo aos apapaatai; e (3) quando os apapaatai são convidados a comer a comida dos Wauja em ocasiões de sua distribuição ritual, ou não. O que a ontologia wauja parece postular é a existência contextual (não essencial, portanto) de aspectos não-humanos na humanidade e aspectos humanos na não-humanidade. A apreensão deste postulado é orientada por lógicas transformacionais que ora aproximam um ser de um pólo ora de outro.

Os movimentos das almas dos humanos (como doentes ou xamãs) e dos yerupoho (como seres vestidos com "roupas") são o paradigma dessa existência contextual.

As almas multiplicadas dos yerupoho não vagueiam por aí simplesmente, o processo de multiplicação guarda valores formais: a multiplicação é também uma trans-forma-ção. Neste sentido, a multiplicação da alma dos yerupoho revela uma variação desconcertante de "roupas", nas quais peixes podem assumir traços passeriformes e vice-versa, panelas assumirem formas de morcegos, e pessoas a forma de desenterradores de mandioca. Esse mundo de transformações múltiplas torna opacos estudos do tipo classificatório-taxonômico da natureza. São as propriedades das transformações que devem ser levadas em conta. Assim, uma cobra pode ser um apapaataiiyajo (monstro), um "espírito", um homem "vestido" nela, ou simplesmente uma cobra. Para todos os efeitos, as múltiplas possibilidades de se ser nos empurram para uma lógica do isto e aquilo e não do isto ou aquilo. Portanto, cobras não são apenas cobras, mas todos os entes do leque potencial de transformações que lhes cabe. Isto é o que também nos ensina Lima a respeito dos Juruna:

“Parecia-me que enquanto nós pretendemos dar conta da totalidade do universo distinguindo de um golpe as três ordens do Homem, da Natureza e da Sobrenatureza, os Juruna procediam de outro modo. Utilizando noções análogas, seu pensamento parece proceder por partes, inventariando cada caso e distinguindo o que é humano, divino e animal na classe dos humanos, na classe dos animais e na dos espíritos" (1999: 47).

\section{E ainda:}

"A tríade de oposições [humano/não-humano, animal/não-animal, espírito/não-espírito] pode se aplicar a cada ente ou tipo de ser, de modo que, então, cada ente consiste em 'um feixe de oposições'; por exemplo, um caititu pode não ser um caititu, não ser um animal, mas espírito" (1999: 47).

O pensamento wauja opera com os mesmos princípios juruna de aproximação máxima entre as séries 
no caso wauja, esse plano tem uma forte ênfase num esquema contínuo-gradativo, que se sustenta em idéias radicais de transformação dos corpos e das almas como condição básica para a alteração dos pontos de vista. A questão central da ontologia wauja parece ser menos preocupada com a forma como os não-humanos vêem os humanos e vice-versa, do que com os modos como aqueles agem sobre estes. E as ações são, em primeira instância, patogênicas, anunciando, por sua vez, que uma transformação está em curso ou que ocorreu há bem pouco ou há muito tempo. O idioma primordial da relação com os seres não-humanos dá-se, portanto, no domínio das diferentes capacidades de manipular as potências xamânica e feiticeira e, conseqüentemente, as transformações, as quais só se manipulam quando se conhecem os seus meios e processos. Esse conhecimento é xamânico em toda a sua extensão, seja na série humana ou na não-humana. Assim, se um humano se Animaliza em função do seu adoecimento, a reversão da transformação compete unicamente a um saber e a uma prática xamânicas. Talvez sejam estas as condições fundamentais para a troca dos pontos de vista: Animalizar-se/xamanizar-se. "O que a teoria juruna enfatiza é a luta entre os pontos de vista e que a realidade é o que o ponto de vista afirma" (Lima 1999: 48, grifos da autora). Se há uma "luta entre pontos de vista" no pensamento wauja, o ponto de vista que procura se afirmar é o da patologia, aquele que é capaz de propor continuidades e descontinuidades entre humanos e não-humanos. 


\section{NOTAS}

1 Este artigo é uma versão resumida e revisada do segundo capítulo da minha tese de doutorado (Barcelos Neto 2004). Agradeço à FAPESP, à CAPES, ao Museu Nacional de Etnologia de Portugal, ao CADCT (atual FAPESB) e ao Funpesquisa/UFSC os auxílios concedidos na forma de bolsas e recursos para a realização dos trabalhos de campo. Quero registrar minha gratidão aos Wauja e a Lux Vidal, Maria Rosário Borges, Pedro Agostinho, Bruna Franchetto, Eduardo Viveiros de Castro, Maria Rosário Carvalho, Michael Heckenberger e Rafael Bastos pelos comentários e incentivos à minha pesquisa no Alto Xingu.

2 Os Wauja são um povo de língua arawak que, há mais de um século, habita as proximidades da margem direita do baixo rio Batovi, na região ocidental da bacia dos formadores do rio Xingu, estado do Mato Grosso, Brasil Central. Desde o século XVIII teve início nessa região a formação de um sistema social multiétnico que integra, além dos Wauja, outros nove grupos de diferentes filiações lingüísticas - Mehinako e Yawalapíti (Arawak); Kuikuro, Kalapalo, Matipu e Nahukwá (Carib); Kamayurá (Tupi-Guarani), Aweti (Tupi) e Trumai (de língua isolada). Os Wauja somam uma população de aproximadamente 360 pessoas, das quais 315 residem numa aldeia circular com o sistema de praça central e casa das flautas. Vide em Franchetto \& Heckenberger (2001) um conjunto de contribuições sobre o sistema xinguano e os povos que o integram.

3 As grafias maiúscula e minúscula empregadas nos nomes dos seres não-humanos dizem respeito à distinção entre pessoas-animais (doravante Animal) e animais-animais (doravante animal) e entre pessoas-plantas (doravante Plantas) e plantas-plantas (doravante planta). Assim, "jaguar" corresponde ao animal da espécie Panthera onca, enquanto "Jaguar" a uma pessoa-jaguar (Yanumaka). Os nomes dos objetos que estão mais próximos da prototipia são também grafados em maiúsculo (e.g. Tankwara, o clarinete; Kawoká, a flauta de madeira; Sapukuyawá, um tipo de máscara vestida por todas as ordens Animais, por Fenômenos Naturais e por Plantas).

4 Conforme discute Viveiros de Castro, a categoria Sobrenatureza permite definir uma terceira categoria de seres da cosmologia xinguana - os espíritos, "que (aliás) não são nem humanos nem animais", não cabendo, portanto, segundo a categorização êmica, na díade Natureza/Cultura - e "designar um contexto relacional específico e uma qualidade fenomenológica própria, distinta tanto da intersubjetividade característica do mundo social (humano) como das relações 'interobjetivas' com os corpos animais" (2002b: 396). É, portanto, nestes sentidos que a categoria sobrenatureza é empregada no presente texto.

5 Os Wauja traduzem yerupoho por "povo antigo" (figura 1). Não tenho como fazer uma etimologia do termo, apenas sei que poho pode ser diretamente traduzido por povo, grupo social. Assim, Yawalapoho são os Yawalapiti; Kupatopoho, o povo-peixe; Yanumakapoho, o povo-jaguar. Segundo a mitologia wauja, todos os yerupoho que vestiram "roupas" ou que foram atingidos pelo sol - quando este foi criado pelo neto de Kwamutõ - transformaram-se em apapaatai.

6 Os "povos Ariranha" incluem as espécies Pteronura brasiliensis (ariranha propriamente dita) e Lutra paranaensis (lontra).

7 Na década de 1960, a espingarda era a metonímia da escolha tecnológica dos brancos (Agostinho 1974: 19-22). Atualmente, com a ampliação do conhecimento indígena sobre a sociedade tecnológica ocidenta le sobre as diferenças entre os brancos, o rol de artefatos oferecidos no passado mítico ampliou-se. Assim, os americanos teriam escolhido também naves espaciais e mísseis, e os paraguaios, objetos malü (falsos, ineficazes, incapazes, ilegítimos), como relógios e pilhas que funcionam mal ou que estragam logo.

8 Ejekepei é o verbo que se refere à ação de soprar (tabaco, por exemplo), rezar (soprar palavras) e tocar um instrumento de sopro (nejekepei tankwara: estou tocando clarinete). Como ação xamânica, o soprar-rezar não somente dá vida aos corpos, como também restaura as almas que Ihe foram raptadas. A seqüência terapêutica rezar-soprar é marcada respectivamente pelos rituais Pukay (de cantos com maracá) e Manapatuwatapai Apapaatai (distribuição de mingau e tabaco seguida de visitação ao doente).

9 Uma versão desse mito foi publicada em Barcelos Neto (1999).

10 A noção wauja de "roupa" (naĩ) implica o uso de máscaras.

110 Em um trabalho anterior (Barcelos Neto 2002: 143-147), mostrei que diferentes parcelas de uma mesma alma podem dar vida tanto a um animal quanto a uma "roupa" sobrenatural. Essas parcelas sempre emanam de um yerupoho, criando uma relação de compartilhamento da upapitsi (princípio vital, alma, consciência) que liga os animais aos Animais. 
12 Segundo as exegeses wauja, o que Kamo roubou dos yerupoho foi a capacidade de cocção e aquecimento do fogo. Os yerupoho continuam a ter fogo, porém ineficaz, embora muitos deles pensem o contrário. Os Wauja sabem que o fogo dos yerupoho "não funciona", mas estes, presos a seus pontos de vista, concebem mundos particulares para si, nos quais os Wauja adentram apenas quando adoecem gravemente ou morrem.

13 Vide em Barcelos Neto (2002: 256-259) a análise de um mito que descreve o processo de transferência do desenterrador de mandioca do domínio de Kukuho (Larva) para o domínio wauja.

14 Rivière desenvolve essa idéia em consonância com uma outra idéia, de que já não compartilho, segundo a qual "máscaras, vestes e ornamentos são meios para domesticar um componente 'animal' essencial à natureza humana" (1995: 191).

15 Em yawalapíti esses afixos-modificadores são, respectivamente, -kumã, -rúru, -mína e -malú (Viveiros de Castro 1977 e $2002 a)$.

16 Os Wauja fazem uma apreciação muito aguda sobre a qualidade dos artefatos industrializados que consomem. Neste sentido, um outro termo usado para expressar a condição -malũ de um objeto é "paraguai", pois, conforme considerações dos Wauja, os produtos contrabandeados daquele país para o Brasil são, em geral, de baixa qualidade. Assim, uma pilha "paraguai" sempre dura pouco em comparação a uma pilha-iyajo ("original"), que dura muito tempo. Como mencionei acima, o mito de origem da humanidade afirma que os paraguaios "só têm coisas-malü" porque eles fizeram uma má escolha ao pegarem um relógio que estragava com pouco tempo de uso.

17 As únicas exceções são o macaco-prego (Cebus apela) e a paca (Cuniculus paca). 


\section{REFERÊNCIAS BIBLIOGRÁFICAS}

AGOSTINHO, Pedro. 1974. Kwarìp. Mito e Ritual no Alto Xingu. São Paulo: EDUSP.

BARCELOS NETO, Aristóteles. 1999. Arte e Mito no Alto Xingu: coleções etnográficas do Museu de Arqueologia e Etnologia da Universidade Federal da Bahia. Salvador: Secretaria de Planejamento, Ciência e Tecnologia/Universidade Federal da Bahia.

2001. “O Universo Visual dos Xamãs Wauja (Alto Xingu)". Journal de la Société des Américanistes 87: 137-160. 2002. A Arte dos Sonhos: uma iconografia ameríndia. Lisboa: Assírio \& Alvim/Museu Nacional de Etnologia.

2004. Apapaatai: rituais de máscaras no Alto Xingu. Tese de Doutorado em Antropologia Social. São Paulo: Universidade de São Paulo.

FAUSTO, Carlos. 2002. "Banquete de Gente: comensalidade e canibalismo na Amazônia". Mana 8(2): 7-44.

FRANCHETTO, Bruna \& M. Heckenberger (orgs.). 2001. Os Povos do Alto Xingu: história e cultura. Rio de Janeiro: Editora UFRJ.

GELL, Alfred. 1998. Art and Agency: an anthropological theory. Oxford: Oxford University Press.

GREGOR, Thomas. 1977. Mehinaku: the drama of daily life in a Brazilian Indian village. Chicago: University of Chicago Press.

IRELAND, Emilienne Marie. 1988. "Cerebral Savage: the white man as symbol of cleverness and savagery in Waurá myth". In Jonathan Hill (ed.) Rethinking History and Myth. Urbana \& Chicago: University of Illinois Press.

2001. “Noções Waurá de Humanidade e Identidade Cultural”. In Bruna Franchetto e Michael Heckenberger (orgs.) Os Povos do Alto Xingu: história e cultura. Rio de Janeiro: Editora UFRJ.

LÉVI-STRAUSS, Claude. 1989. Des Symboles et leurs Doubles. Paris: Plon.

LIMA, Tânia Stolze. 1996. “O Dois e seu Múltiplo: reflexões sobre o perspectivismo em uma cosmologia tupi”. Mana 2(2): 21-47.

. 1999. "Para uma Teoria Etnográfica da Distinção Natureza e Cultura na Cosmologia Juruna". Revista Brasileira de Ciências Sociais 14(40): 43-52.

RIVIÈRE, Peter. 1995. “AAE na Amazônia". Revista de Antropologia 38(1): 191-203.

. 2001. "A Predação, a Reciprocidade e o Caso das Guianas". Mana 7(1): 31-53.

TAYLOR, Anne-Christine. 1994. "The Soul's Body and its States: an Amazonian perspective on the nature of being human". Journal of the Royal Anthropological Institute (nova série) 2: 201-215.

VIVEIROS DE CASTRO, Eduardo. 1977. Indivíduo e Sociedade no Alto Xingu: os Yawalapíti. Dissertação de Mestrado em Antropologia Social. Rio de Janeiro: Museu Nacional da Universidade Federal do Rio de Janeiro.

. 1978. “Notas sobre a Cosmologia Yawalapíti”. Religião e Sociedade 3: 163-174.

1979. "A Fabricação do Corpo na Sociedade Xinguana". Boletim do Museu Nacional (nova série) Antropologia 
. 1996. “Os Pronomes Cosmológicos e o Perspectivismo Ameríndio". Mana 2(2): 115-144.

2002a. “Esboço de Cosmologia Yawalapíti”. In A Inconstância da Alma Selvagem e Outros Ensaios de Antropologia. São Paulo: Cosac \& Naify.

2002b. "Perspectivismo e Multinaturalismo na América Indígena". In A Inconstância da Alma Selvagem e Outros Ensaios de Antropologia. São Paulo: Cosac \& Naify.

. 2002c. "Atualização e Contra-efetuação do Virtual: o processo do parentesco". In A Inconstância da Alma Selvagem e Outros Ensaios de Antropologia. São Paulo: Cosac \& Naify. 
“Doença de Índio": O princípio patogênico da alteridade e os modos de transformação em uma cosmologia amazônica

\section{RESUMO}

Durante meus trabalhos de campo entre os índios Wauja do Alto Xingu, recolhi várias narrativas sobre pessoas da aldeia que tinham virado "bicho" quando estiveram gravemente doentes. A maioria retornou à sua condição humana graças às intervenções de xamãs visionário-divinatórios e de altos especialistas rituais. Este artigo descreve as séries de transformações entre humanos e não-humanos na cosmologia wauja e discute como são distribuídos e colocados em relação os atributos da humanidade, animalidade e da monstruosidade.

PALAVRAS-CHAVE: transformações cosmológias na Amazônia; índios Wauja; doença; noções de animalidade e humanidade

\section{"Indian IIIness": The pathogenic principle of alterity and the means of transformation in an Amazonian cosmology}

\section{ABSTRACT}

During my fieldwork among the Wauja Indians of the Upper Xingu river I collected several narratives of local people who had suffered animal transformations when severely ill. Most of them returned to their human condition after the interventions of highly specialized shamans and ritual singers and dancers. This article describes the series of transformations between humans and non-humans in the Wauja cosmology and discusses how the attributes of humanity, animality and monstruosity are distributed and set in relation.

KEY WORDS: cosmological transformations in Amazonia; Wauja Indians; illness; notions of animality and humanity.

Recebido em 14/03/2006

Aprovado em 05/05/2006 